\title{
Gene expression and maturation evaluation of sheep oocytes cultured in medium supplemented with natural antioxidant source
}

\author{
I. A. H. Barakat ${ }^{1,2 \#}$, R. A. Alajmi ${ }^{1}$, K. M. A. Zoheir ${ }^{2}$, L. M. Salem ${ }^{2}$ \& A. R. Al-Hemidiy ${ }^{1}$ \\ ${ }^{1}$ Department of Zoology, College of Science, King Saud University, P.O. Box 2455, Riyadh 11451, Kingdom of Saudi \\ Arabia \\ ${ }^{2}$ Department of Cell Biology, National Research Centre, 33 Bohouth St., Dokki, Giza, Egypt
}

Received 2 March 2017; Accepted 25 April 2017; First published online 21 December 2017)

\begin{abstract}
Copyright resides with the authors in terms of the Creative Commons Attribution 4.0 South African Licence.
See: http://creativecommons.org/licenses/by/4.0/za

Condition of use: The user may copy, distribute, transmit and adapt the work, but must recognise the authors and the South African Journal of Animal Science.
\end{abstract}

\begin{abstract}
Any improvements in assisted reproduction techniques at experimental level are important in in vitro production of large animal and human embryos. The in vitro embryo production system includes three major steps, namely in vitro maturation of the primary oocytes, in vitro fertilization of the matured oocytes, and in vitro culture of presumptive embryos. The success of in vitro fertilization and embryo culture depends on the success of in vitro maturation. Fenugreek seed extract (FSE) is an important source of steroid hormones, antioxidants, and anti-inflammatories. This study aims to investigate the effect of FSE on the maturation progression, glutathione (GSH) concentration, and expression of certain genes controlling maturation such as growth differentiation factor-9 (GDF-9), transforming growth factor beta receptor 1 (TGF $\beta R 1$ ), activin A receptor type II-like 1 (ACVRL1), hyaluronan synthase 2 (HAS2), C-Myc, B-cell leukaemia/lymphoma gene-2 (BCL-2), and BCL2-associated X protein (Bax) of matured sheep oocytes. To carry out this study, cumulusoocyte complexes (COCs) aspirated from sheep ovaries were cultured in TCM-199 medium supplemented with various concentrations of FSE $(0,1$ and $10 \mu \mathrm{g} / \mathrm{mL})$. The results indicated that the mean values of matured oocytes were 65.2 compared with 47.8 in the control group. Concerning the candidate genes, expression was improved in oocytes matured with FSE when compared with oocytes cultured without extract. In conclusion, the addition of FSE to the maturation medium at 1 or $10 \mu \mathrm{g} / \mathrm{mL}$ concentrations improved the maturation of oocytes.
\end{abstract}

Keywords: Fenugreek seed extract, in vitro maturation, maturation genes, oocytes, sheep

\# Corresponding author: ibrahimahb@yahoo.com

\section{Introduction}

In vitro maturation (IVM) is one of the essential steps in the in vitro fertilization (IVF) process (Mahdi et al., 2008). In vivo conditions cannot be mimicked totally under in vitro situations, but developmental capabilities of oocytes can be improved by adding various substances to the maturation media (Choi et al., 2001).

Fenugreek (Trigonella foenum graecum L.) is an annual plant from the family PapilionaceaeLeguminosae and is cultivated extensively in India, the Mediterranean region, North Africa and Yemen (Kassem et al., 2006). Studies have shown that fenugreek seed has antioxidant properties (Hibasami et al., 2003). In addition, fenugreek seed polyphenols have been shown to prevent oxidative haemolysis and lipid peroxidation induced by hydrogen peroxide $\left(\mathrm{H}_{2} \mathrm{O}_{2}\right)$ in vitro in human erythrocytes (Kaviarasan et al., 2004). In the authors' previous study (Barakat et al., 2010), the addition of fenugreek extract to a maturation medium was found to enhance the quality of a less effective medium (CR1aa), and to optimize the effect of TCM-199 on in vitro maturation of Egyptian buffalo oocytes. Moreover, oral administration of fenugreek extract increased the total number and quality of collected mice oocytes significantly, as mentioned by Hassan \& Abdel-Wahhab (2006).

Spices and herbs possess antioxidant activity and can be applied to preserve lipid peroxidation in biological systems (Mohsen et al., 2012). Fenugreek (Trigonella foenum graecum) is an important spice. Its dried seeds have wide applications in food and beverages as flavouring additives and in medicines. The antioxidant property of the plant material is due to the presence of many active phytochemicals, including 
vitamins, flavonoids, terpenoids, carotenoids, cumarins, curcumins, lignin, saponin, and sterols. Currently, research is directed towards finding naturally occurring antioxidants of plant origin (Mohsen et al., 2012). Antioxidants exert their mode of action by suppressing the formation of reactive oxygen species by inhibiting enzymes or by chelating trace elements (Young \& Woodside, 2001). Therefore, it has been used for liver therapy (Yoo et al., 2008).

A major problem in IVF is that oocytes and embryo culture are affected by increased oxidative stress (Gaspmini et al., 2000; Guerinet al., 2001; Sadeesh et al., 2014). Oxidative stress damages gametes and embryos owing to free radicals that are generated by endogenous processes such as normal cellular metabolism and exogenous factors such as chemicals that are added to the culture media, hyperoxia, and exposure to light (lleana et al., 2012). During in vivo oocyte maturation, fertilization and embryonic development, enzymatic and non-enzymatic antioxidants are present in follicular fluid (Catherine et al., 2009).

Cumulus-oocyte complexes (COCs) are present in the reproductive tract secretions that aid in controlling the propagation of free radical reactions, thus providing precise regulation of the redox state of the embryo. The innate antioxidant defences in embryos are not sufficient to counter the oxidative stress encountered during in vitro culture (Dröge, 2002; Oyawoye et al., 2003; Tracy et al., 2009; Rajesh et al., 2010). Numerous antioxidant chemicals have been added as supplements to culture media in mammalian in vitro embryo culture (Rajesh et al., 2010). These include proteins, vitamins, antioxidant enzymes, metal chelators, thiol compounds, vitamin E, a-tocopherol, and its derivatives, ascorbic acid and cysteamine (Sies \& Stahl, 1995; Olson \& Seidel; 2000; Guerin et al., 2001; Rajesh et al., 2010; Beheshti et al., 2011; lleana et al., 2012). In addition, Barakat et al. (2014) found that green tea extract used as an antioxidant in culture media of sheep oocytes resulted in an improvement of embryo development to blastocyst stage.

The molecular modifications of COCs during maturation include accumulation of mRNA and proteins, which originate from long stages of development during oogenesis and folliculogenesis (Kempisty et al., 2011b). In metaphase II (MII) oocytes, these accumulated molecules become a template for the synthesis of proteins during the consecutive steps of embryo growth. During the long period of oocyte maturation and differentiation (folliculo- and oogenesis), large amounts of mRNA and proteins become synthesized and accumulated (Kempisty et al., 2011a). These oocyte-specific molecules, also called 'maternal factors', are involved in sequential steps of embryogenesis. Li et al. (2010) described maternal-effect genes as mRNA templates, which appear between the last stages of oocyte maturation and embryonic genome activation, and are necessary for early embryo development. Molecular changes in COCs include the accumulation of appropriate amounts of several substrates, enzymes and other molecules involved in biochemical reactions inside the cytoplasm. Biochemical changes have pronounced effects on the cell, which may be defined as the ability of the oocyte to change the cell organellum activity in relation to modified culture conditions (for example using transcription or translation activators or inhibitors) (Kempisty et al., 2011a). Bone morphogenetic protein 15 (BMP15) and growth differentiation factor-9 (GDF-9) are oocyte-specific growth factors that appear to play key roles in granulosa cell development and fertility in most mammalian species (Eppig, 2001). GDF-9 and bone morphogenetic protein 15 (BMP15) are two members of the transforming growth factor receptor superfamily (Chang, 2002) that are expressed by oocytes and play key roles in granulosa cell development and fertility in animal models (Dong et al., 1996; Yan et al., 2001). Moreover, the actions of recombinant GDF-9 resemble those of native factors secreted by growing oocytes isolated from secondary follicles in promoting the synthesis of proteins by granulosa cells associated with the secondary to tertiary transition stage during follicular development (Latham et al., 2004). Oocytes are essential for follicular formation and development (Eppig, 2001; Matzuk et al., 2002), because oocyte-derived factors such as GDF-9 and BMP15 are involved in regulation of follicle formation, growth and granulocyte differentiation (Peng et al., 2013; Baerwald et al., 2012). Genes that encode steroidogenic enzymes for androgen production are expressed to a certain extent in stromal cells (SCs). These results confirm that granulosa cells (GCs) stimulate ovarian stromal cells differentiation into theca cells (TCs). After that, they lose the capacity to stimulate the steroidogenic function of TCs and retain only the capacity of maintaining their steroidogenic function (Spaczynski et al., 2005). In addition, and according to Hengde et al. (2013), supplementing a-lipoic acid significantly reduced the cellular apoptosis rate of nucleus transfer blastocysts by inhibiting the expression of apoptotic activators such as Bax, Bad, Caspase-3, and CytC genes and promoting cumulus-oocyte complexes to synthesize GSH and express antioxidant enzymes such as GPX4 and SOD genes. During embryonic development, cell apoptosis is a major phenomenon that eliminates abnormal cells through embryo internal cell selection (Shimizuet al., 2012).

Owing to the persisting low efficiency of IVM of some mammalian oocytes, the aim of this study was to examine the role of FSE as a natural source for antioxidants during IVM of Neaimi sheep oocytes, and its effect on gene expression and the maturation of oocytes. 


\section{Materials and Methods}

All chemicals used in this study were purchased from Sigma-Aldrich Chemicals (St. Louis, MO, USA), unless otherwise specified.

The FSE was extracted once at the beginning of the experiments. Fenugreek seeds were heated in water $(10 \mathrm{~g} / 100 \mathrm{~mL})$ until boiling, and then evaporated to $25 \%$ of its original volume. Afterwards, the suspension was spread and left to dry completely (Maghsoud et al., 2013).

To evaluate the role of FSE as a natural source for antioxidants and estradiol $17 \beta$, IVM was carried out under these culture conditions: i) defined maturation medium (GI); ii) defined maturation medium + 1 $\mu \mathrm{gFSE} / \mathrm{mL}$ (GII); and iii) defined maturation medium $+10 \mu \mathrm{gFSE} / \mathrm{mL}$ (GIII). The defined maturation medium consisted of Tissue culture medium-199 with earl's $+10 \%$ foetal bovine serum (Gibco, USA) + 0.023 IU $\mathrm{FSH} / \mathrm{ml}+0.23 \mathrm{IU} \mathrm{LH} / \mathrm{ml}+1 \mu \mathrm{g}$ estradiol $17 \beta / \mathrm{ml}+50 \mu \mathrm{g} / \mathrm{ml}$ kanamycin. Group I served as the control group and Groups II and III were considered to evaluate the effect of FSE on the IVM outcome.

Ovaries of adult sheep were obtained from a local slaughterhouse, placed in isotonic sodium chloride solution $(0.9 \% \mathrm{NaCl})$, and supplemented with penicillin $(200 \mathrm{IU} / \mathrm{mL})$ and streptomycin $(200 \mu \mathrm{gg} / \mathrm{mL})$ at $30-35$ ${ }^{\circ} \mathrm{C}$. Collected ovaries were transported to the laboratory within one to three hours of collection. Ovaries were washed three times with pre-warmed fresh saline $\left(37^{\circ} \mathrm{C}\right)$, and all visible follicles with a diameter from 2 to 8 $\mathrm{mm}$ were aspirated with a 20-gauge needle. After aspiration, COCs were selected (Figure1) for IVM. They were washed three times with maturation medium and were cultivated for $22-24$ hours at $38.5{ }^{\circ} \mathrm{C}$ at $5 \% \mathrm{CO}_{2}$ and high humidity conditions.

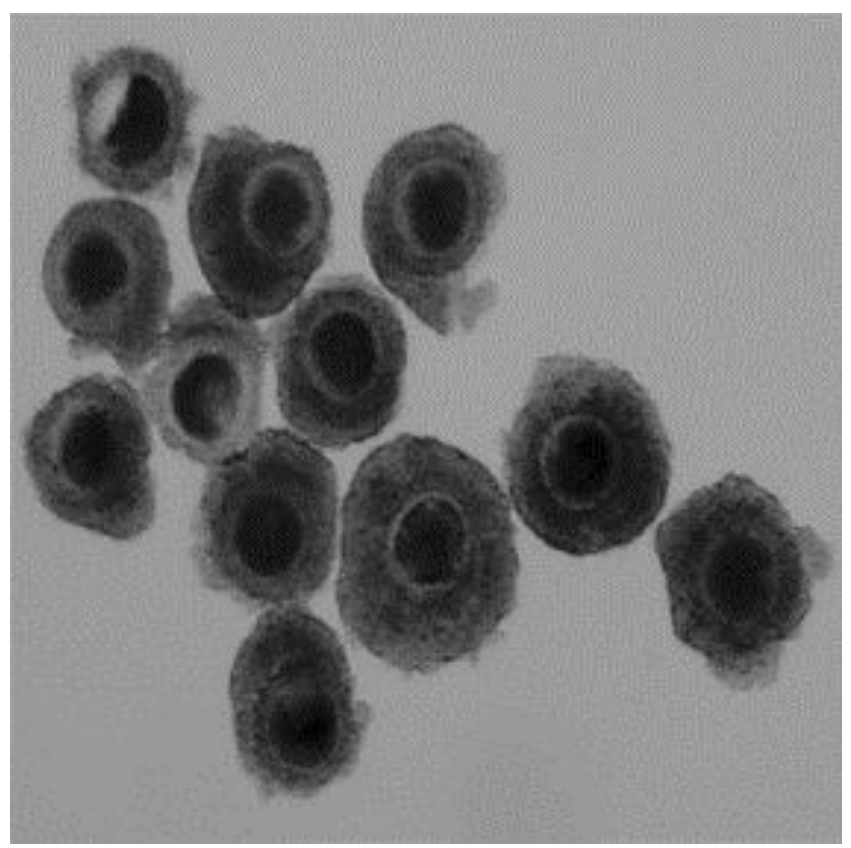

Figure 1 Different grades of cumulus oocyte complexes before in vitro maturation

Estimation of nuclear maturation was carried out with the classical method. After 22-24 hours, matured oocytes were denuded with $0.1 \%$ hyaluronidase and gentle mouth pipetting. Denuded oocytes were then fixed in acetic acid : ethanol $(1: 3, \mathrm{v} / \mathrm{v})$ for $24-48$ hours, and were stained with $1 \%$ aceto-orcein in $45 \%$ ( $\mathrm{v} / \mathrm{v})$ acetic acid (Rao et al., 2002). The stages of oocytes were classified according to Santos et al. (2006): intact germinal vesicle (GV), namely unidentifiable nucleolus and very fine filaments of chromatin; germinal vesicle breakdown (GVBD), presence of different patterns of chromatin condensation, chromosomes coiled up and no visible individual chromosomes; metaphase I (MI); anaphase I (AI); and metaphase II (MII).

The intracellular content of GSH was measured as described by Funahashi et al. (1994). The frozen samples were thawed at room temperature, then frozen again. This procedure was repeated three times. Five microlitres of $0.2 \mathrm{M}$ sodium phosphate containing $10 \mathrm{mM}$ EDTA (Sigma, assay buffer) and $5 \mathrm{~mL}$ of 1.25 $\mathrm{M}$ phosphoric acid (Fluka, Buchs, Switzerland) were added to a $1.5 \mathrm{~mL}$ microfuge tube containing 30 oocytes. Samples were stored at $-80^{\circ} \mathrm{C}$ until use. Concentrations of GSH in the oocytes were determined with the dithionitrobenzonic acid-glutathione disulphide (DTNB-GSSG) reductase-recycling assay (Anderson, 1985). Briefly, $700 \mu \mathrm{L}$ of $0.33 \mathrm{mg} \mathrm{NADPH} / \mathrm{mL}$ in stock buffer, $100 \mu \mathrm{L}$ of $6 \mathrm{mM}$ DTNB in stock buffer and 190 
$\mu \mathrm{L}$ water were added with mixing into the microfuge tube. To initiate the reaction, $10 \mu \mathrm{L}$ glutathione reductase was added with mixing. The formation of 5-thio-2-nitrobenzoic acid was followed continuously and the absorbance was monitored at $412 \mathrm{~nm}$ with a spectrophotometer (Ultraspec-2000, Pharmacia Biotech Ltd., Cambridge, UK) and recorded at 30 seconds and 5 minutes. The reagent blank and GSH standards $(0.1-1.0 \mathrm{nmol})$ were assayed under the same conditions. The amount of GSH in each sample was determined by comparing it with a standard curve prepared at the same time.

The oocytes were washed three additional times in the phosphate buffer solution provided with a Cellsto-cDNA II kit (Ambion, Texas, USA), then transferred in a minimal volume of medium to $1.5 \mathrm{~mL}$ tubes and centrifuged at $17000 \mathrm{~g}$ for $10 \mathrm{~min}$ at $4{ }^{\circ} \mathrm{C}$ to recover the cell pellet. All samples were stored at $-80{ }^{\circ} \mathrm{C}$ until assayed. cDNA was synthesized according to the manufacturer's instructions.

To prepare a cell lysate, $50 \mu \mathrm{L}$ of the provided cell lysis buffer was added to a $0.5 \mathrm{~mL}$ tube containing the pelleted cells and mixed using a vortex for $5 \mathrm{~min}$. The suspension was then heated using a block-type thermal cycler system according to the manufacturer's instructions.

Cell lysates were supplemented with RNase-free certified DNase I (10 IU/ $/ \mathrm{LL}$ ) provided in the Cells-tocDNA II kit $\left(0.16 \mathrm{IU} / \mu \mathrm{L}\right.$ final concentration) and incubated at $37^{\circ} \mathrm{C}$ for 5 minutes. Immediately after the end of the incubation, each tube was heated for $15 \mathrm{~min}$ at $75^{\circ} \mathrm{C}$ to inactivate the DNase. To synthesize the first strand of cDNA according to the Cells-to-cDNA II kit protocol, $5 \mu \mathrm{L}$ cell lysate, $4 \mu \mathrm{L}$ dNTP mix, $2 \mu \mathrm{L}$ oligo (dT) and $5 \mu \mathrm{L}$ RNase-free water were assembled in an RNase-free $0.5 \mathrm{~mL}$ tube, then heated for $3 \mathrm{~min}$ at $70^{\circ} \mathrm{C}$. Afterwards, this mixture was cooled on ice, then $2 \mu \mathrm{L} 10 \times \mathrm{RT}$ buffer, $1 \mu \mathrm{L} \mathrm{M}-\mathrm{MLV}$ reverse transcriptase and $1 \mu \mathrm{L}$ RNase inhibitor were added to the reaction tubes. Reverse transcription was carried out for $30 \mathrm{~min}$ at 42 ${ }^{\circ} \mathrm{C}$, followed by incubation at $95{ }^{\circ} \mathrm{C}$ for $10 \mathrm{~min}$. RT-minus products were produced as controls for each sample to demonstrate that the template for the PCR product was CDNA, not genomic DNA contamination.

Genes encoding activin like kinase5 (ALK5), GDF-9, transforming growth factor-receptor 1: (TGF-R1), HAS2, BCL-2, C-Myc, Bax and P54 transcript quantity were measured by Real Time-Polymerase change reaction (RT-PCR). The sequences of primers were designed using the GenBank genes sequences and synthesized by Applied Biosystems UK, Ltd. (Table 1). The RT-PCR cycling conditions consisted of initial denaturation step at $94{ }^{\circ} \mathrm{C}$ for $4 \mathrm{~min}$, followed by 35 cycles of denaturation step at $94{ }^{\circ} \mathrm{C}$ for $30 \mathrm{sec}$, annealing step at $60^{\circ} \mathrm{C}$ for $30 \mathrm{sec}$., and extension step at $72{ }^{\circ} \mathrm{C}$ for 45 seconds. This cycle was followed by final extension at $72{ }^{\circ} \mathrm{C}$ for $5 \mathrm{~min}$. The data were presented as the fold change in gene expression normalized to the endogenous reference gene ( $\beta$ - actin) and relative to a calibrator. The RT-PCR data were analysed using the relative gene expression (that is, $2^{-\Delta \Delta C}$ ) method, as described in Applied Biosystems User Bulletin No. 2. The RT-PCR machine used was that of Applied Biosystems ${ }^{\circledR}$. The expression was normalized to the endogenous reference gene ( $\beta$ - actin) and relative to a calibrator.

Table 1 Primer sequences and GenBank accession numbers of genes under study and housekeeping gene

\begin{tabular}{lcccc}
\hline Gene & Forward Primer & Reverse primer & $\begin{array}{c}\text { Annealing } \\
\text { temperature }\end{array}$ & $\begin{array}{c}\text { Accession } \\
\text { numbers }\end{array}$ \\
\hline GDF-9 & AGCTGAAGTGGGACAACTGG & ACACAGGATGGTCTTGGCAC & $60{ }^{\circ} \mathrm{C}$ & $\underline{\text { NM } 001142888.2}$ \\
TGFßR1 & ATGCCAATGGAGCAGCTAGG & ATGGCAGTTTCCTGGGTCTG & $60^{\circ} \mathrm{C}$ & $\underline{\text { XM } 004004226.1}$ \\
ACVRL1 & GACCCCTTGAAACCTCTCG & GAGGCGACGTACCTTCTAGC & $60^{\circ} \mathrm{C}$ & $\underline{\text { XM } 004007400.1}$ \\
HAS2 & GTCTGTTTGCCTTGGCAGTG & TGTTGGTGAGAGGACCATGC & $60^{\circ} \mathrm{C}$ & $\underline{\text { XM } 004015096.1}$ \\
C-MyC & ACACACAACGTTTTGGAGCG & GGGATCTGGTCACGAAGAGC & $60^{\circ} \mathrm{C}$ & NM_001009426.1 \\
BCL-2 & ATGACTTCTCTCGGCGCTAC & CTCCACACACATGACCCCTC & $60^{\circ} \mathrm{C}$ & $\mathrm{HM630309.1}$ \\
Bax & TGCATCCACCAAGAAGCTGAG & AGGAAGTCCAATGTCCAGCC & $60^{\circ} \mathrm{C}$ & XM_004015363.1 \\
B- Actin & AGGCCAACCGTGAGAAGATG & AATCGCACGAGGCCAATCTC & $60^{\circ} \mathrm{C}$ & $\underline{\text { NM 001009784.1 }}$
\end{tabular}

GDF-9: growth differentiation factor-9

TGFBR 1: transforming growth factor beta receptor 1

ACVRL1: activin A receptor type II-like 1

HAS2: hyaluronan synthase 2

Statistical analyses for all data were carried out using one-way analysis of variance (ANOVA) followed by Duncan's test using the SPSS program. Results were expressed as mean \pm SE. A probability of $P \leq 0.05$ was considered statistically significant. 


\section{Results}

In terms of the effect of adding FSE to the maturation medium on the nuclear maturation of sheep oocytes, the results in Table 2 show no significant differences between Groups II and III for all nuclear stages (GV, GVBD, MI, Al, and MII), while there were significant differences between Groups II, III and control in relation to GVBD, MI, and Anaph.I stages. On the other hand, there was no significant difference in GV stage among groups. As for the MII stage, the mean value of Group III was significantly higher when compared with Group I (control), while it was not significantly different from Group II. At the same time, the mean values of Groups I and II were not significantly different (Table 2).

Table 2 Effect of fenugreek seed extract on in vitro nuclear maturation (mean \pm SEM) of Saudi Arabian sheep oocytes

\begin{tabular}{|c|c|c|c|c|c|c|}
\hline \multirow{2}{*}{\multicolumn{2}{|c|}{ Traits Groups }} & \multicolumn{5}{|c|}{ Nuclear maturation } \\
\hline & & GV & GVBD & MI & Al & MII \\
\hline \multicolumn{2}{|c|}{$\begin{array}{l}\text { Estradiol } 17 \beta \text { (Control) } \\
\text { (Group I) }\end{array}$} & $15.6^{\mathrm{a}} \pm 0.7$ & $11.4^{\mathrm{a}} \pm 1.0$ & $12.4^{\mathrm{a}} \pm 1.1$ & $8.2^{a} \pm 0.7$ & $47.8^{\mathrm{a}} \pm 6.3$ \\
\hline & $\begin{array}{l}1 \mu \mathrm{g} / \mathrm{ml} \\
\text { (Group II) }\end{array}$ & $13.2^{\mathrm{a}} \pm 0.7$ & $16.2^{b} \pm 1.3$ & $16.4^{b} \pm 1.0$ & $11.0^{\mathrm{b}} \pm 0.7$ & $51.4^{\mathrm{ab}} \pm 2.7$ \\
\hline FSE & $\begin{array}{l}10 \mu \mathrm{g} / \mathrm{ml} \\
\text { (Group III) }\end{array}$ & $15.2^{\mathrm{a}} \pm 0.9$ & $15.2^{b} \pm 0.7$ & $15.8^{b} \pm 1.1$ & $10.8^{b} \pm 0.9$ & $65.2^{b} \pm 3.8$ \\
\hline
\end{tabular}

Results of GSH concentrations, as shown in Figure 2, reveal a significant increase in GSH levels in oocytes matured in a maturation medium supplemented with $10 \mu \mathrm{g} / \mathrm{mL}$ (Group III) $(0.33 \pm 0.1 \mathrm{nmol} /$ oocytes) compared with Group I and II ( $0.15 \pm 0.03$ and $0.18 \pm 0.7 \mathrm{nmol} /$ oocytes, respectively).

\section{GTH concentration ( $\mathrm{nmol}$ )}

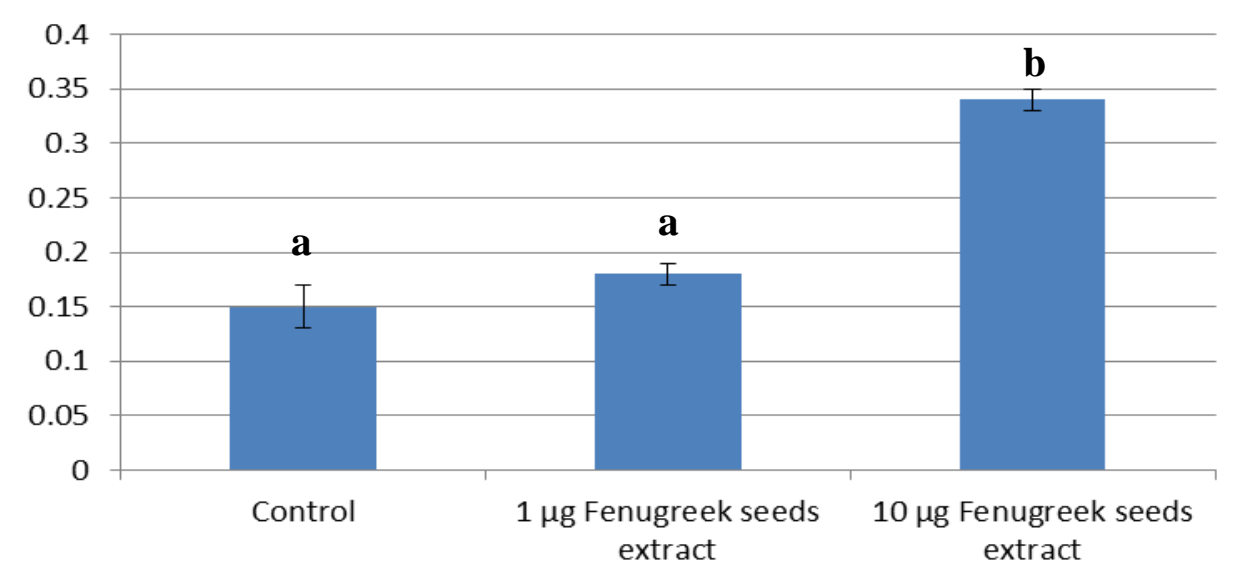

Figure 2 Effect of fenugreek seed extract on the concentration of the intracellular glutathione in sheep oocytes during in vitro maturation

The RT-PCR analyses (Table 3) showed that the mRNA expression of genes encoding ACVRL1, GDF-9, TGF $\beta R 1$, HAS2, and C-Myc had a significant increase in Groups II and III compared with Group I (control) $(P \leq 0.05)$. Results of mRNA RT-PCR showed that expression of both BCL-2 (pro-survival) and Bax (pro-apoptosis) were significantly decreased in Group II and III if compared with Group I (control group) ( $P$ $\leq 0.05$ ). In addition, there were no significant differences on the expression of these all genes between Group II and III $(P \leq 0.05)$. 
Table 3 Effect of administrations of fenugreek seed extract on the expression of activin A receptor type II-like 1 , growth differentiation factor-9, transforming growth factor beta receptor 1, hyaluronan synthase 2, C-Myc, $\mathrm{BCL} 2$-associated $\mathrm{X}$ protein and B-cell leukaemia/lymphoma gene-2 genes in sheep oocytes matured in vitro (mean \pm SEM)

\begin{tabular}{|c|c|c|c|c|c|c|c|c|}
\hline \multirow{2}{*}{\multicolumn{2}{|c|}{ Traits groups }} & \multicolumn{5}{|c|}{ The fold change in gene expression } & \multirow[b]{2}{*}{ Bax } & \multirow[b]{2}{*}{ BCL-2 } \\
\hline & & ACVRL1 & GDF-9 & TGF $\beta R 1$ & HAS2 & C-Myc & & \\
\hline \multicolumn{2}{|c|}{$\begin{array}{l}\text { Control } \\
\text { (Group I) }\end{array}$} & $1^{a} \pm 0.07$ & $1.0^{\mathrm{a}} \pm 0.05$ & $1.0^{\mathrm{a}} \pm 0.05$ & $1.0^{\mathrm{a}} \pm 0.06$ & $1.0^{\mathrm{a}} \pm 0.07$ & $1.00^{\mathrm{b}} \pm 0.07$ & $1.00^{\mathrm{b}} \pm 0.05$ \\
\hline & $\begin{array}{l}1 \mu \mathrm{g} / \mathrm{ml} \\
\text { (Group II) }\end{array}$ & $1.45^{\mathrm{b}} \pm 06$ & $1.51^{b} \pm 0.03$ & $1.41^{b} \pm 0.06$ & $1.23^{b} \pm 0.04$ & $1.95^{\mathrm{b}} \pm 0.08$ & $0.60^{\mathrm{a}} \pm 0.03$ & $0.61^{a} \pm 0.04$ \\
\hline FSE & $\begin{array}{l}10 \mu \mathrm{g} / \mathrm{ml} \\
\text { (Group III) }\end{array}$ & $1.54^{b} \pm 0.9$ & $1.47^{\mathrm{b}} \pm 0.04$ & $1.48^{\mathrm{b}} \pm 0.04$ & $1.34^{b} \pm 0.03$ & $2.01^{b} \pm 0.06$ & $0.52^{\mathrm{a}} \pm 0.04$ & $0.57^{\mathrm{a}} \pm 0.03$ \\
\hline
\end{tabular}

${ }^{\text {ab }}$ Mean values in the same columns with different superscripts differ significantly $(P \leq 0.05)$

FSE: fenugreek seed extract

GDF-9: Growth differentiation factor-9

TGF $\beta R$ 1: Transforming growth factor beta receptor 1

ACVRL1: Activin A receptor type II-like 1

HAS2: Hyaluronan synthase 2

BCL-2: B-cell leukaemia/lymphoma gene-2

Bax: BCL2-associated $X$ protein

\section{Discussion}

This study is the first to report the effect of FSE as a natural antioxidant source on gene expression and in vitro maturation of sheep oocytes. The effect of FSE on the in vitro maturation of oocytes and thus the development of embryos was reported recently (Barakat \& Ahmed, 2013). Previous studies have shown that increasing the oxidative stress in the maturation medium affects the success of maturation and thus the production of embryos in different animals (Geshi et al., 2000; Harvey et al., 2002; Watson et al., 1994). Oxidative stress results from the increase of reactive oxygen species, that is, free radicals (Miesel et al., 1993). Moreover, free radicals have been found in the cultivation media for aerobic organisms, oocytes and embryos (Guerin et al., 2001; Martin-Romero et al., 2008). Additionally, in vitro maturation of oocytes requires the presence of estradiol in the medium to complete the meiotic division. COCs secrete estradiol during cultivation in a steroid-free medium (Pellicer; 1997; Dode \& Graves, 2002; Mingoti et al., 2002). The current study agreed with previous studies concerning the importance of supplementing the maturation medium with antioxidants and estradiol to improve in vitro oocyte maturation. The results of the current study showed that the mean of maturation, intracellular GSH concentration and gene expression increased when using FSE compared with the control group. In addition, these findings agree with the results reported by Sur et al. (2001), Hibasami et al. (2003), Barakat \& Ahmed (2013) and Barakat et al. (2014), who found that the addition of a source of antioxidants in the maturation medium enhanced the in vitro maturation rate and embryonic development. Previous studies showed that there is a relationship between the maturation rate and the concentration of intracellular GSH (Eppig, 1996; Abeydeera et al., 2000; Luberda, 2005). This is illustrated by the current results, in which the authors found a significant increase in the in vitro maturation rate of sheep oocytes with an increased concentration of GSH. In contrast, there is no relationship between GSH concentration and the blastocyst formation rate (Viet et al., 2009).

According to the current results, GDF-9 was upregulated in Groups I and II compared with control. Furthermore, the levels of other related genes to DD9 as HAS2, TGF $\beta R 1$, transforming growth factor receptor 1, and C-Myc were increased. In this case, GDF-9 promoted granulosa cell proliferation, suppressed the expression of LH/CG receptor (LHCGR) in granulosa cells, and stimulated the expression of genes in cumulus cells, HAS2, and prostaglandin synthetase 2 (Ptgs2) (also known as cyclooxygenase 2 (Cox2)), which are required for the expansion of the cumulus oophorus and ovulation, thus mimicking the actions of native oocyte-derived factors observed in oocyte cumulus cell co-culture experiments (Elvin et al., 1999; Elvin et al., 2000). GDF-9, zygote arrest 1 (ZAR1) and BMP15, which are maternal effect genes, are expressed preferentially in the oocyte and are usually present in early embryos and then degraded at the time of maternal-to-embryonic transition, in which there is a shift from mRNAs and proteins stored in the oocyte to those transcribed and synthesized by the embryo (Yadav et al., 2013). GDF-9 is an oocyte-specific paracrine factor, which is expressed throughout most stages of folliculogenesis and persists after fertilization 
through pre-implantation embryo development (Pennetier et al., 2004). GDF-9 and BMP15, both of which are members of the transforming growth factor-b superfamily, are expressed in oocytes and are secreted to act on cumulus cells (McNatty et al., 2005). BMP15 transcript has been shown to be present in oocytes and embryos in cattle (Pennetier et al., 2004), sheep (Bebbere et al., 2008) and pigs (Li et al., 2008) because apoptosis is believed to play an important role in protecting the cells from cytotoxic conditions by removing damaged cells. The current data showed that Bax and BCL-2 (apoptotic or bad genes) were significantly down-regulated in Groups I and II compared with control, where the inhibition of the levels of expression of these two genes occurred in the oocytes treated with FSE in the maturation medium. In contrast with the current results, Yadav et al. (2013) demonstrated that exposure of buffalo oocytes and embryos to elevated temperatures for a duration of time that is physiologically relevant severely compromises their developmental competence, increases apoptosis and affects stress-, apoptosis- and development-related genes (GDF-9, caspase-3, BID and Bax, BCL-XL and MCL-1, GLUT1, ZAR1, and BMP). The current results found that the levels of expression of both -2 and apoptotic Bax were significantly decreased in mature oocyte cells that were treated with FSE, as in Groups I and II, compared with control group. Mingning et al. (2013) concluded that the interaction of granulosa cells with ovarian cells could reduce the frequency of apoptotic cells of ovarian cortical stromal cells by decreasing the expression of pro-apoptotic genes Bax and bad mRNA in ovarian cortical stromal cells, ovarian medullary stromal cells and theca cells, and increasing the expression of pro-survival gene BCL-2 mRNA in ovarian stromal cells to promote ovarian cell proliferation. These findings suggested that granulosa cells prevented cell apoptosis of ovarian cortical stromal cells, and enhanced the capacity of anti-apoptosis of ovarian cortical stromal cells, ovarian medullary stromal cells and theca cells, but had no detrimental effect on cell proliferation of ovarian stromal cells. The present results indicated that adding FSE to the maturation medium significantly reduced BCL-2 and Bax genes expression in embryos, thus improving oocyte quality by reducing BCL-2 and Bax gene expression and inhibiting cell apoptosis. In this study, the authors also observed that treatment of cells with FSE resulted in decreased levels of both BCL-2 and Bax mRNA. According to its structure and function, BCL-2 is classified as a proapoptotic gene, anti-apoptotic gene, and regulated gene. Sun et al., (2012) concluded that Bax initiate apoptosis by forming a pore in the mitochondrial outer membrane, which allows cytochrome $C$ to escape into the cytoplasm and activates the pro-apoptotic caspase cascade. In addition, the BCL-2-associated death promoter (Bad) protein is a pro-apoptotic member of the BCL-2 gene family, which is involved in initiating apoptosis. According to the current data, FSE downregulated Bax and BCL-2 with high significance so it prevented cell apoptosis and enhanced the anti-apoptotic machinery. Thus, BCL-2, Bad, and Bax measurements in cells may reflect cell apoptotic degree. Studies in mice and cows have reported that granulosa cells are metabolically coupled to oocytes via gap junctions throughout their growth and during initial stages of maturation. This metabolic coupling is responsible for protein and phosphorylation changes associated with the resumption of meiosis (Spaczynski et al., 2005). During oocyte maturation from GV to MII stage, oocytes generally cannot express genes, but need to synthesize some proteins and their phosphorylation changes for cytoplasmic maturation to promote nuclear changes. In the current study, that authors detected ACVRL1, GDF-9, transforming growth factor beta receptor 1 (TGF $\beta R 1$ ), HAS2, $\beta$-cell lymphoma protein 2 (BCL-2), C-Myc, Bax and P54 gene expressions in MII oocytes. Although the oocyte itself does not express some genes during maturation, this gap junction of oocyte with cumulus cells may result in expressing some genes in cumulus cells to be transported into oocytes during IVM. This inference needs to be confirmed in future studies.

\section{Conclusion}

The addition of FSE to oocyte IVM medium at $10 \mu \mathrm{g} / \mathrm{mL}$ improved the maturation rate and increased the intracellular GSH concentration and gene expression of the studied genes. This improvement is attributed to the antioxidant effect regulating growth factor genes, anti-apoptotic genes and apoptotic genes.

\section{Acknowledgements}

The authors would like to extend their sincere appreciation to the Deanship of Scientific Research at King Saud University for its funding this Research Group No (RGP -1438-058).

\section{Authors' Contributions}

$I A H B$ and RAA were in charge of the experimental design and implementation. IAHB and KMAZ wrote the manuscript. ARAH and RAA participated in correcting the manuscript. IAHB carried out statistical analysis.

\section{Conflict of Interest Declaration}

The authors wish to confirm that there are no conflicts of interest associated with the publication of this manuscript, and that it has been read and approved by all authors. 


\section{References}

Abeydeera, L.R., Wang, W.H., Cantley, T.C., Rieke, A., Murphy, C.N., Prather, R.S. \& Day, B.N., 2000. Development and viability of pig oocytes matured in a protein-free medium containing epidermal growth factor. Theriogenology 54, 787-797.

Anderson, M., 1985. Determination of glutathione and glutathione disulfide in biological samples. Method. Enzymol. 113, 548-555.

Baerwald, A.R., Adams, G.P. \& Pierson, R.A., 2012. Ovarian antral folliculogenesis during the human menstrual cycle: A review. Hum. Reprod. Update 18, 73-91.

Barakat, I.A.H. \& Ahmed, R.A., 2013. Effects of fenugreek seed extract on in vitro maturation and subsequent development of sheep oocytes. Pakistan J. Zool. 45, 1679-1686.

Barakat, I.A.H., Ahmad, R.A. \& Ahmed, M.R., 2014. Antioxidant effect of green tea leaves extract on in vitro production of sheep embryos. Pakistan J. Zool. 46, 167-175

Barakat, I.A.H., Hassan, A.M., Alam, S.S. \& Khalil, W.K.B., 2010. Genetic and biochemical effects of natural extracts on in vitro maturation of Egyptian buffalo oocytes. Cytologia 75, 243-253.

Bebbere, D., Bogliolo, L., Ariu, F., Fois, S., Leoni, G.G., Tore, S., Succu, S., Berlinguer, F., Naitana, S. \& Ledda, S., 2008. Expressionpattern of zygote arrest 1 (ZAR1), maternal antigen that embryo requires (MATER), growth differentiation factor 9 (GDF-9) and bone morphogenetic protein 15 (BMP15) genes in ovine oocytes and in vitroproduced pre-implantation embryos. Reprod. Fert. 20, 908-915.

Beheshti R., Mohammadi, R.A., Giasi, G.J., Ghaemmaghami, S. \& Houshangi, A.F., 2011. Effect of Antioxidant Supplements on in Vitro Maturation of Bovine Oocyte. Adv. Env. Biol. 5, 1473-1475.

Birjees, B.S., Bhanger, M.L. \& Memon, S.H., 2008. Antioxidative activity of extracts from fenugreek seeds (Trigonella foenum-graecum). Pakistan J. Ann. Environ. Chem. 9, 78-83.

Catherine, M.H.C., Sajal, G. \& Ashok, A., 2009. Could oxidative stress influence the in-vitro maturation of oocytes? Reprod. Biomed. Online. 18, $864-880$.

Chang, H., Brown C.W. \& Matzuk M.M., 2002. Genetic analysis of the mammalian transforming growth factor-beta superfamily. Endocr. Rev. 23, 787-823.

Choi, Y.H., Carnevale, E.M., Siedel, G.E. \& Squires, E.L., 2001. Effect of gonadotropins on bovine oocyte matured in TCM-199. Theriogenology 56, 661-670.

Dode, M.A.N. \& Graves, C.N., 2002. Involvement of steroid hormones on in vitro maturation of pig oocytes. Theriogenology 57, 811-821.

Dong, J.W., Albertini, D.F., Nishimori, K., Kumar, T.R., Lu, N.F. \& Matzuk, M.M., 1996. Growth differentiation factor-9 is required during early ovarian folliculogenesis. Nature $383,531-535$.

Dröge, W., 2002. Free radicals in the physiological control of cell function. Physiol. Rev. 82, 47-95.

Elvin, J.A., Clark, A.T., Wang, P., Wolfman, N.M. \& Matzuk, M.M.,1999. Paracrine actions of growth differentiation factor9 in the mammalian ovary. Mol. Endocrinol. 13, 1035-1048.

Elvin, J.A., Yan, C.N. \& Matzuk, M.M., 2000. Growth differentiation factor-9 stimulates progesterone synthesis in granulosa cells via a prostaglandin E-2/EP2 receptor pathway. Proceedings of the National Academy of Sciences of the USA 97, 10288-10293.

Eppig, J.J., 1996. Coordination of nuclear and cytoplasmic oocyte maturation in eutherian mammals. Reprod. Fert. Develop. 8, 485-489.

Eppig, J.J., 2001. Oocyte control of ovarian follicular development and function in mammals. Reproduction 122, 829-838.

Funahashi, H., Cantley, T.C., Stumpf, T.T. \& Day, B.,1994. Use of low-salt culture medium with elevated oocytes glutathione levels. Biol. Reprod. 51, 633-639.

Gaspmini, B., Neglia, G., Di Palo, R., Campanile, G. \& Zicarelli, L., 2000. Effect of cysteamine during in vitro maturation on buffalo embryo development. Theriogenology 54, 1537-I542.

Geshi, M., Takenouchi, N., Yamauchi, N. \& Nagai, T., 2000. Effects of sodium pyruvate in non serum maturation medium on maturation, fertilization, and subsequent development of bovine oocytes with or without cumulus cells. Biol. Reprod. 63, 1730-1734.

Guerin, P., El Mouatassim, S. \& Menezo, Y., 2001. Oxidative stress and protection against reactive oxygen species in the pre-implantation embryo and its surroundings. Hum. Reprod. Update 7, 175-189.

Harvey, A.J., Kind, K.L. \& Thompson, J.G., 2002. REDOX regulation of early embryo development. Reproduction 123 , 479-486.

Hassan, A.M. \& Abdel-Wahhab, M.A., 2006. Antioxidant effect of parsley and panax ginseng extract against alteration induced in reproductive functions in male mice. Egypt. J. Hosp. Med. 22, 60-72.

Hengde, Z., Bin, W., Hongliang, L., Mingning, Q., Jun, L., Yong, Z. \& Fusheng, Q., 2013. Improving development of cloned goat embryos by supplementing a-lipoic acid to oocyte in vitro maturation medium. Theriogenology 80 , 228-233.

Hibasami, H., Moteki, H. \& Ishikawa, K., 2003. Protodioscin isolated from fenugreek (Trigonella foenum-graecum L.) induces cell death and morphological change indicative of apoptosis in leukemic cell line $\mathrm{H}-60$, but not in gastric cancer cell line KATO III. Int. J. Mol. Med. 11, 23-26.

Ileana, M.N.P., Andrea, H., Marius, Z. \& Vasile, M., 2012. Alpha-tocopherol and Ascorbic Acid Combinations Influence the Maturation of Sheep Oocytes. Anim. Sci. Biotechnol. 45, 310 - 313.

Kassem, A., Abdulwali, A., Molham, A. \& Mohammed, A., 2006. Evaluation of the potential antifertility effect of fenugreek seeds in male and female rabbits. Contraception 73, 301-306. 
Kaviarasan, S., Vijayalakshmi, K. \& Anuradha, C.V., 2004. A polyphenol-rich extract of fenugreek seed protects erythrocytes from oxidative damage. Plant Food. Hum. Nutr. 59, 143-147.

Kempisty, B., Bukowska, D., Piotrowska, H., Zawierucha, P., Sniadek, P., Walczak, R., Dziuban, J., Antosik, P., Jaskowski, J., Brussow, K.P., Nowicki, M. \& Zabel, M., 2011a. Selected molecular and microfluidic aspects of mammalian oocyte maturation perspectives: A review. Vet. Med-Czech. 56, 367-378.

Kempisty, B., Walczak, R., Antosik, P., Szczepańska, P., Wozna, M., Bukowska, D., Zaorska, K., Dziuban, J. \& Jaskowski, J.M., 2011b. Mammalian oocyte and embryos developmental competence evaluation systems based on the microfluidic technology Lab-on-Chip (in Polish). Med. Weter. 67, 25-28.

Latham, K.E., Wigglesworth, K., McMenamin, M. \& Eppig, J.J., 2004. Stage-dependent effects of oocytes and growth differentiation factor 9 on mouse granulose cell development: advance programming and subsequent control of the transition from pre-antral secondary follicles to early antral tertiary follicles. Biol. Reprod. 70, 1253-1262.

Li, H., Kuo, T., Yang, H., Chen, L., Li, S.S. \& Huang, H., 2008. Differential gene expression of bone morphogenetic protein 15 and growth differentiation factor 9 during in vitro maturation of porcine oocytes and early embryos. Anim. Reprod. Sci. 103, 312-322.

Li, L., Zheng, P. \& Dean, J., 2010. Maternal control of early mouse development. Development 6, 859-870.

Luberda, Z., 2005. The role of glutathione in mammalian gametes. Reprod. Biol. 5, 5-17.

Maghsoud, P., Saeedeh, Y.S., Ali, A.M. \& Sajad, A., 2013. The effect of endurance training and extract of fenugreek seed on serum visfatin and vaspin levels in diabetic rats. Ann. Biol. Res. 4, 301-306.

Mahdi, K.M., Ahmad, Z.S., Morteza, D., Hamid, K. \& Framarz, G., 2008. In vitro maturation of sheep oocytes in different concentrations of mare serum. Afr. J. Biotechnol. 7, 3380-3382.

Martin-Romero, F.J., Miguel-Lasobras, E.M., Dominguez-Arroyo, J.A., Gonzalezcarrera, E. \& Alvarez, I.S., 2008. Contribution of culture media to oxidative stress and its effect on human oocytes. Reprod. Biomed. 17, 652-661.

Matzuk, M.M., Burns, K.H., Viveiros, M.M. \& Eppig, J.J., 2002. Intercellular communication in the mammalian ovary: Oocytes carry the conversation. Science 296, 2178-2180.

McNatty, K.P., Smith, P., Moore, L.G., Reader, K., Lun, S., Hanrahan, J.P., Groome, N.P., Laitinen, M., Ritvos, O. \& Juengel, J.L., 2005. Oocyte-expressed genes affecting ovulation rate. Mol. Cell Endocrinol. 234, 57-66.

Miesel, R., Drzejczak, P.J. \& Kurpisz, M., 1993. Oxidative stress during the interaction of gametes. Biol. Reprod. 49, 918923.

Mingning, Q., Fusheng, Q., Chengquan, H., Bin, W., Jun, L., Zhongcai, Y., Feng, S. \& Yong, Z., 2013. Effects of granulosa cells on steroidogenesis, proliferation and apoptosis of stromal cells and theca cells derived from the goat ovary. J. Steroid Biochem. 138, 325-333.

Mingoti, G.Z., Garcia, J.M. \& Rosa-e-Silva, A.A., 2002. Steroidogenesis in cumulus cells of bovine cumulus oocyte complexes matured in vitro with BSA and different concentrations of steroids. Anim. Reprod. Sci. 69, 175-186.

Mohsen, A., Hassan, R. \& Tina, B., 2012. Physiological and pharmaceutical effect of fenugreek: A review. IOSR J. Pharm. 2, 49-53.

Olson, S.E. \& Seidel, G.E., 2000. Culture of in vitro-produced bovine embryos with vitamin E improves development in vitro and after transfer to recipients. Biol. Reprod. 62, 248-252.

Oyawoye, O., Gadir, A.A., Garner, A., Constantinovici, N., Perrett, C. \& Hardiman, P., 2003. Antioxidants and reactive oxygen species in follicular fluid of women undergoing IVF: Relationship to outcome. Hum. Reprod. 18, 22702274.

Paynton, B.V., 1998. RNA-binding proteins in mouse oocytes and embryos: Expression of genes encoding Y box, DEAD box RNA helicase, and poly A binding proteins. Dev. Genet. 23, 285-298.

Pellicer, A., 1997. Oestrogens and follicular and oocyte development. Hum. Reprod. Update. 3, 93 - 94

Peng, J., Li, Q., Wigglesworth, K., Rangarajan, A., Kattamuri, C., Peterson, R.T., Eppig, J.J., Thompson, T.B. \& Matzuk, M.M., 2013. Growth differentiation factor 9: Bone morphogenetic protein 15 heterodimers are potent regulators of ovarian functions. Proceedings of the National Academy of Sciences of the USA 110, E776-E785.

Pennetier, S., Uzbekova, S., Perreau, C., Papillier, P., Mermillod, P. \& Dalbi es-Tran, R., 2004. Spatio-temporal expression of the germ cell marker genes MATER, ZAR1, GDF-9, BMP15, and VASA in adult bovine tissues, oocytes, and pre-implantation embryos. Biol. Reprod. 71, 1359-1366.

Rajesh, N., Madhira, B.S. \& Deecaraman, M., 2010. Effect of a-tocopherol supplementation on in vitro maturation of sheep oocytes and in vitro development of pre-implantation sheep embryos to the blastocyst stage. J. Assist. Reprod. Gen. 27, 483-490.

Rao, B.S., Naidu, K.S., Amarnath, D., Vagdevi, R., Rao, A.S., Brahmaiah, K.V. \& Rao, V.H., 2002. In vitro maturation of sheep oocytes in different media during breeding and non-breeding seasons. Small Rumin Res. 43, 31-36.

Sadeesh, E.M., Shah, F., Balhara, A.K., Thirumaran, S.M.K., Yadav, S. \& Yadava, P.S., 2014. Effect of growth factor and antioxidant on in vitro maturation of oocytes and cleavage rates of in vitro produced Indian buffalo (Bubalus bubalis) embryos. Vet. Arhiv 84, 459-474.

Santos, L.C., Rodrigues, B.A. \& Rodrigues, J.L., 2006. In vitro nuclear maturation of bitch oocytes in the presence of polyvinyl-pyrrolidone. Anim. Reprod. 3, 70-75.

Shimizu, T., Kaji, A., Murayama, C., Magata, F., Shirasuna, K., Wakamiya, K. \& Miyamoto, K.O., 2012. Effects of interleukin- 8 on estradiol and progesterone production by bovine granulosa cells from large follicles and progesterone production by luteinizing granulosa cells in culture. Cytokine 57, 175-181.

Sies, H. \& Stahl, W., 1995. Vitamins, E. and C, $\beta$-carotene, and other carotenoids as antioxidants. Am. J. Clin. Nutr. 62 , 1315S-1321S.

Spaczynski, R.Z., Tilly, J.L., Mansour, A. \& Duleba, A.J., 2005. Insulin and insulin-like growth factors inhibit and luteinizing hormone augments ovarian theca-interstitial cell apoptosis. Mol. Hum. Reprod. 11, 319-324. 
Sun, Y.L., Zhang, J., Ping, Z.G., Wang, C.Q., Sun, Y.F., Chen, L., Li, X.Y., Li, C.J., Zhu, X.L., Liu, Z., Zhang, W. \& Zhou, $X ., 2012$. Relationship between apoptosis and proliferation in granulosa and theca cells of cystic follicles in sows. Reprod. Domest. Anim. 47, 601-608.

Sur, P., Das, M. \& Gomes, A., 2001. Trigonella foenum graecum (fenugreek) seed extract as an antineoplastic agent. Phytother. Res. 15, 257-259.

Tracy, L., Kristin, R., Scott, M. \& James, D.G., 2009. Glutathione content and antioxidant enzyme expression of in vivo matured sheep oocytes. Anim. Reprod. Sci. 116, 265-273.

Viet Linh, N., Dang-Nguyen, T.Q., Nguyen, B.X., Manabe, N. \& Nagai, T., 2009. Effects of cysteine during in vitro maturation of porcine oocytes under low oxygen tension on their subsequent in vitro fertilization and development. J. Reprod. Dev. 55, 594-598.

Watson, A.J., Watson, P.H., Warnes, D., Walker, S.K., Armstrong, D.T. \& Seamark, R.F., 1994. Pre-implantation development of in vitro-matured and in vitro-fertilized ovine zygotes: Comparison between co-culture on oviduct epithelial cell monolayers and culture under low oxygen atmosphere. Biol. Reprod. 50, 715-724.

Yadav, A., Singh, K.P., Singh, M.K., Saini, N., Palta, P., Manik, R.S., Singla, S.K., Upadhyay, R.C. \& Chauhan, M.S., 2013. Effect of physiologically relevant heat shock on development, apoptosis and expression of some genes in buffalo (Bubalus bubalis) embryos produced in vitro. Reprod. Domest. Anim. 48, 858-865.

Yan, C., Wang, P., DeMayo, J., DeMayo, F.J., Elvin, J.A. \& Carino, C., 2001. Synergistic roles of bone morphogenetic protein 15 and growth differentiation factor 9 in ovarian function. Mol. Endocrinol. 15, 854-866.

Yoo, K.M., Lee, C.H., Lee, H., Moon, B. \& Lee, C.Y., 2008. Relative antioxidant and cytoprotective activities of common herbs. Food Chem. 106, 929-936.

Young, I.S. \& Woodside, J., 2001. Antioxidants in health and disease. J. Clin. Pathol. 54, 176-186. 